DOI: https://doi.org/10.24127/ajpm.v9i2.2735

\title{
LEARNING OBSTACLE SISWA PADA MATERI LINGKARAN
}

\author{
Cita Dwi Rosita ${ }^{*}$, Anggita Maharani ${ }^{2}$, Tonah $^{3}$, Munfi $^{4}$ \\ $1^{*}, 2,3,4$ Pendidikan Matematika, Universitas Swadaya Gunung Djati, Cirebon, Indonesia \\ *Corresponding author. FKIP Universitas Swadaya Gunung Djati Jl. Perjuangan No 1, 45132, Cirebon, Indonesia \\ E-mail: $\quad$ citadwirosita@gmail.com ${ }^{\left.{ }^{*}\right)}$
}

Received 01 April 2020; Received in revised form 14 June 2020; Accepted 30 June 2020

\begin{abstract}
Abstrak
Penelitian ini dilatarbelakangi oleh permasalahan pembelajaran yang muncul pada siswa ketika mempelajari topik lingkaran. Berdasarkan hasil studi pendahuluan ditemukan bahwa siswa belum dapat menyelesaikan permasalahan terkait lingkaran apabila dihadapkan pada konteks masalah berbeda dari yang sudah dipelajari bersama guru. Tujuan penelitian dimaksudkan untuk mengeksplor learning obstacle yang dialami siswa dalam menyelesaikan permasalahan tersebut. Studi ini menggunakan metode kualitatif dengan desain penelitian didactical design research (DDR). Subjek penelitian adalah 35 siswa kelas IX pada salah satu SMP di Kabupaten Cirebon. Data penelitian diperoleh melalui instrumen tes pemahaman konsep lingkaran dan pedoman wawancara. Hasil penelitian menunjukkan bahwa kurang terampilnya siswa dalam menyelesaikan permasalahan pada topik lingkaran dengan konteks yang berbeda adalah dikarenakan adanya learning obstacle siswa pada konsep keliling dan luas lingkaran terkait dengan merepresentasikan ide matematis ke dalam bentuk representasi simbolik dan visual. Sementara itu, learning obstacle siswa pada topik garis singgung terkait dengan kemampuan mengaitkan antar konsep matematis, serta menerapkan konsep matematis dalam kehidupan nyata.
\end{abstract}

Kata kunci: Didactical design research; learning obstacle; lingkaran.

\begin{abstract}
This research is motivated by the learning problems that arise in students when studying circle topics. Based on the preliminary study, it was found that students have not been able to solve problems related to the circle when faced with a different problem context than what was studied with the teacher. The purpose of the study is intended to explore the students' learning obstacles in solving these problems. This study uses qualitative methods with didactical design research (DDR) design. The research subjects were 35 students of class IX in one junior high school in Cirebon Regency. The research data was obtained through an understanding test instrument of circle concept and interviews. The results showed that students were less skilled in solving problems on the topic of circles with different contexts was due to students' learning obstacles in in the circumference concept and area of the circle associated with representing mathematical ideas in the form of symbolic and visual representations. Meanwhile, students' learning obstacles on tangent topics is related to the ability to link between mathematical concepts, and to apply mathematical concepts in real life.
\end{abstract}

Keywords: Circle; didactical design research; learning obstacle.

\section{PENDAHULUAN}

Mempelajari ilmu matematika sebagaimana para ahli matematika terdahulu menemukan konsep-konsep matematis akan melatih kemampuan siswa dalam memecahkan masalah. Melatih siswa sebagai seorang problem solver dapat dilakukan melalui pemberian masalah-masalah matematis yang tiduk rutin sehingga akan mempengaruhi cara berpikir siswa dalam memanfaatkan serta mengaplikasikan matematika pada masalahmasalah dunia nyata. Hal ini sejalan dengan kajian Branca (Rosita, 2014) yang menyimpulkan bahwa mempelajari matematika melalui masalah yang tak rutin akan mengembangkan kemampuan siswa untuk menggunakan 
matematika dalam kehidupan seharihari.

Untuk alasan tersebut di atas maka memahami secara utuh topiktopik matematika di setiap tingkat, termasuk di dalamnya tingkat Sekolah Menengah Pertama (SMP) merupakan hal yang mutlak diupayakan. Beberapa topik matematika yang dipelajari oleh siswa SMP adalah lingkaran dan garis singgung lingkaran. Kedua topik ini merupakan bagian dari geometri yang aplikasi konsepnya cukup dekat dengan kehidupan sehari-hari.

Pada kenyataannya, kemampuan siswa dalam memahami kedua topik di atas masih menyisakan permasalahan dalam pembelajaran. Berdasarkan hasil pengamatan dan wawancara terhadap beberapa siswa SMP di Kabupaten Cirebon diperoleh data bahwa pada umumnya kualitas kemampuan siswa dalam menyelesaikan soal-soal matematis terkait lingkaran apabila dihadapkan pada konteks yang berbeda dengan apa yang sudah diberikan oleh guru masih rendah (Diana, Vitaloka, Wulandari \& Munfi, 2019).

Untuk mengungkap penyebab permasalahan di atas, dilakukan kajian terhadap beberapa hasil penelitian relevan baik yang terkait langsung dengan materi lingkaran maupun materi matematika lainnya. Hasil kajian dapat disimpulkan bahwa penyebab kurangnya pemahaman siswa adalah adanya suatu hambatan belajar (learning obstacle) yang dialami siswa baik dilihat dari aspek kesiapan belajarnya, kepemilikan konsep matematisnya, maupun keterurutan materi pelajarannya (Sulistiawati, Suryadi \& Fatimah, 2015; Perbowo \& Anjarwati, 2017; Astuti, 2017; Rohimah, 2017; Rosita, Nopriana \& Silvia, 2019; Jannah, Nusantara, Sudirman, Sisworo, Yulianto \&
Amiruddin, 2019; Prasetyo, Herman \& Aljupri, 2020). Learning obstacle akan menghambat siswa dalam melakukan proses berpikir dan bagaimana memahami suatu konsep (Harel \& Sowder, 2005).

Brousseau (2002) membagi learning obstacle menjadi tiga jenis yakni ontogenical learning obstacle, didactical learning obstacle dan epistemological learning obstacle. Ontogenical learning obstacle adalah kesulitan belajar terjadi disebabkan aspek psikologis, dimana siswa mengalami kesulitan belajar karena faktor kesiapan mental, dalam hal ini cara berfikir siswa yang belum masuk karena faktor usia. Didactical learning obstacle adalah kesulitan belajar yang terjadi karena kekeliruan penyajian, dalam hal ini bahan ajar yang digunakan siswa dalam belajar dapat menimbulkan miskonsepsi. Epistemological learning obstacle adalah kesulitan belajar siswa karena pemahaman siswa tentang sebuah konsep yang tidak lengkap, hanya dilihat dari asal-usulnya saja sehingga menyebabkan putusnya proses kepemilikan pengetahuan secara utuh.

Data hasil studi pendahuluan secara tidak langsung menunjukkan terputusnya kemampuan siswa baik dalam mengaitkan materi yang sedang dipelajari dengan pengetahuan prasyarat juga mengaplikasikan pengetahuan yang telah diterimanya secara benar. Oleh karena itu learning obstacle yang dikaji pada penelitian ini difokuskan pada jenis epistemological learning obstacle (epistemologis). Hal tersebut sesuai dengan temuan Cornu \& Bachelard (Tall, 2002) yang menunjukkan bahwa terjadinya hambatan epistemologis pada siswa akan menyebabkan adanya ketidakmampuan pada siswa dalam memberikan respons juga memahami 
suatu pengetahuan baru secara utuh. Selain itu, hambatan epistemologi juga akan mengakibatkan siswa kurang dapat merespons serta menggunakan pengetahuan yang telah diperoleh sebelumnya. Dengan demikian learning obstacle jenis epistemologis akan sangat mempengaruhi kinerja kemampuan pemecahan masalah matematis siswa. Apabila sistem pemerolehan pengetahuan baru siswa terganggu maka dimungkinkan akan terjadinya stagnasi atau bahkan penurunan pengetahuan seseorang.

Penelitian-penelitian terkait data learning obstacle peserta didik telah dilakukan oleh peneliti-peneliti sebelumnya (Sulistiawati, et al., 2015; Perbowo \& Anjarwati, 2017; Astuti, 2017; Rohimah, 2017; Aprilia, Praja \& Noto, 2018; Noto, Pramuditya \& Fiqri, 2018; Rosita, et al., 2019; Jannah, et al., 2019; Bakar, Suryadi \& Darhim, 2019; Cesaria \& Herman, 2019; Noto, Priatna \& Dahlan, 2019; Prasetyo, et al., 2020). Namun demikian pengungkapan learning obstacle yang dikaitkan dengan sudut pandang siswa dalam memeroleh pengetahuan baru, belum pernah dilakukan oleh penelitianpenelitian yang telah disebutkan di atas.

Menurut Suryadi (2019), cara pandang siswa terhadap materi prasyarat maupun pemerolehan pengetahuan baru dibagi kedalam beberapa perspectif yaitu perceptual, memorial, instropective, dan aprioribelive. Untuk mengungkap hal tersebut maka pada penelitian ini dilakukan wawancara terhadap subyek penelitian dengan berpedoman pada keempat perspektif di atas. Hal ini dilakukan agar hasil penelitian tidak hanya mengungkap kelemahan siswa tetapi juga mengungkap penyebab kelemahan siswa.
Berdasarkan uraian permasalahan serta hasil temuan studi-studi relevan sebelumnya, maka dipandang penting untuk mengkaji lebih mendalam hambatan apa saja yang dialami siswa dalam mempelajari topik lingkaran dan garis singgung lingkaran. Oleh karena itu, tujuan penelitian ini adalah untuk mengeksplorasi learning obstacle siswa dalam mempelajari topik lingkaran dan garis singgung lingkaran.

\section{METODE PENELITIAN}

Metode penelitian yang digunakan adalah metode penelitian kualitatif dengan model DDR/Didactical Design Research (Suryadi, 2013). Metode kualitatif digunakan dengan tujuan untuk mendeskripsikan hasil analisis terhadap learning obstacle yang dialami siswa pada materi lingkaran dan garis singgung lingkaran. Dalam penelitian ini, proses memunculkan learning obstacle pada siswa dilakukan pada tahapan analisis situasi didaktis yang selanjutnya akan dikembangkan ke tahapan metapedadidaktik dan tahapan restropektif pada penelitian selanjutnya.

Subyek pada penelitian ini melibatkan 35 siswa kelas IX pada salah satu SMP Negeri di Kabupaten Cirebon yang dipilih secara purposif. Sementara itu, teknik pengumpulan data dilakukan melalui pemberian tes, teknik wawancara, dan dokumentasi.

Ketika subyek penelitian telah diberikan tes tertulis terkait materi lingkaran dan garis singgung lingkaran, selanjutnya adalah mendokumentasikan hasil pekerjaan siswa tersebut untuk dianalisis data learning obstacles nya serta kemudian melakukan wawancara kepada sebagian subyek yang dianggap perlu ditelusuri serta dimintai klarifikasinya untuk mendapatkan respons setelah mengerjakan instrumen tes. Sementara itu, butir pertanyaan 
wawancara dibuat berdasarkan empat cara melakukan justifikasi yang terdiri dari penjelasan siswa seputar obstacles yang dihadapi dilihat dari sudut pandang perceptual, memorial, instropective, dan aprioribelive (Suryadi, 2019).

Berikut ini dijelaskan bagaimana keempat cara pandang siswa dalam memberikan justifikasi yang telah dilaksanakan selama penelitian. Butir wawancara yang menggambarkan aspek perseptual merupakan bentuk pertanyaan yang meminta justifikasi siswa berdasarkan sesuatu yang pernah dilihatnya dalam pembelajaran. Dalam studi ini, bentuk pertanyaan yang diberikan berupa meminta siswa untuk mendeskripsikan konsep lingkaran itu sendiri. Butir wawancara yang menggambarkan aspek memorial merupakan pertanyaan yang meminta siswa memberikan justifikasi tentang konsep pada topik lingkaran maupun garis singgung lingkaran berdasarkan pengetahuan siswa yang didapat dari berbagai sumber yang tidak hanya melalui pembelajaran di sekolah. Sudut pandang instrospective merupakan cara dimana siswa mencari pembenaran melalui pencarian informasi yang mendukung pendapatnya sendiri dengan mengaitkan beberapa materi prasyarat. Sudut pandang yang terakhir yaitu aprioribelieve merupakan cara siswa membuat kesimpulan terhadap pendapat yang dimilikinya dan merasakan bagaimana hasil pembelajaran yang sudah didapatkannya.

\section{HASIL DAN PEMBAHASAN}

Hasil penelitian ini mencakup 4 tipe learning obstacle terkait konsep keliling lingkaran, luas daerah lingkaran dan garis singgung lingkaran.

\section{Soal Nomor 1}

Seekor domba diikat dengan tali pada sebuah tiang. Jika tali yang digunakan berukuran 1,8 $\mathrm{m}$ maka dapatkah anda menghitung luas daerah yang dapat dijelajahi oleh domba tersebut? Konsep apa yang digunakan untuk menyelesaikan soal di atas?

Pada soal Nomor 1, siswa diminta untuk menghitung luas daerah maksimum yang dapat dijangkau oleh seekor domba yang terikat pada tiang dengan tali berukuran 1,8 m. Luas maksimum daerah yang dibentuk merupakan luas daerah lingkaran dengan jari-jari 1,8 meter. Artinya, siswa harus menghitung luas daerah lingkaran dengan jari-jari yang sudah diketahui dalam soal. Berdasarkan hasil jawaban siswa diperoleh data dari 35 subyek masih ada 4 subyek yang keliru menjawab. Berikut adalah contoh jawaban siswa yang masih mengandung kekeliruan.

Siswa 1

$$
\begin{gathered}
\text { Luas Lingkaran }=\pi r=3,14 \times 1,8 \\
=5,562 \mathrm{~m}^{2}
\end{gathered}
$$

Siswa 2

$$
\begin{aligned}
\text { Luas Lingkaran } & =\pi r^{2}=3,14 \times 0,6^{2} \\
& =1,1304 \mathrm{~m}^{2}
\end{aligned}
$$

Jawaban Siswa 1 menggambarkan bahwa siswa tersebut sudah mengetahui bahwa besaran pembangun luas lingkaran adalah nilai $\square$ dan jari-jari. Selain itu, siswa juga dapat membangun representasi internalnya dari ide matematis yang terdapat pada soal meskipun formula luas yang dibentuknya masih keliru. Sementara itu, representasi internal yang dihasilkan Siswa 2 belum tepat sepenuhnya, dimana konsep jari-jari diinterpretasikan dengan konsep diameter. Namun demikian, formula luas lingkaran yang dihasilkan oleh Siswa 2 sudah benar. 
DOI: https://doi.org/10.24127/ajpm.v9i2.2735

Untuk keperluan mengetahui penyebab kekeliruan yang dialami oleh kedua siswa tersebut, dilakukan penelusuran melalui wawancara. Adapun transkrip wawancara adalah sebagai berikut.

Peneliti : Waktu kamu mempelajari keliling, luas dan garis singgung lingkaran, kesulitan apa yang kamu alami?

S-1 : Saya tidak terlalu paham

Peneliti : Di bagian mana yang kamu tidak paham?

S-1 : Rumus keliling saya tahu, rumusnya $2 \pi \times \mathrm{r}$ (sambil memberi kesan sedang mengingat)

Peneliti : Rumus luas lingkaran bagaimana?

S-1 : $\square r$

Peneliti : Kamu yakin?

S-1 : Lupa bu, tidak hapal

Peneliti : Selain belajar bersama guru di sekolah, apakah kamu juga mengulang dan mempelajarinya kembali di rumah?

S-1;S-2 : Kadang-kadang. Kalau guru memberi PR

Peneliti : Apakah kamu juga belajar dari sumber belajar selain yang digunakan di sekolah?

S-1 : Saya hanya belajar dari buku paket yang digunakan di sekolah

S-2 : Saya punya buku lain yang saya gunakan untuk membantu saya mengerjakan $P R$ yang diberikan guru

Peneliti : Apakah kamu merasa puas kalau sudah menjawab soal matematika?

S-1 : Saya merasa sangat senang kalau sudah bisa

\section{menyelesaikan soal. \\ Peneliti : Bagaimana kamu meyakinkan diri bahwa jawaban yang kamu dapatkan sudah benar? \\ S-1;S-2 : Menunggu dibahas oleh guru di kelas}

Berdasarkan skrip wawancara di atas, secara perseptual siswa belum mendapatkan konsep luas lingkaran yang benar secara utuh sehingga justifikasi yang diberikannya juga keliru. Secara memorial, kekeliruan dalam menyajikan konsep luas lingkaran disebabkan karena kemandirian siswa dalam meyakinkan apa yang sudah diperolehnya cukup rendah. Hal tersebut ditunjukkan dengan pernyataan siswa yang menunggu pembahasan bersama guru di kelas untuk mengetahui kebenaran dari jawaban yang telah disusunnya.

Soal Nomor 2

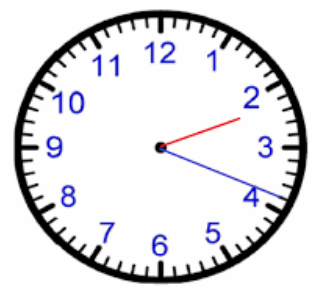

Jarum panjang pada jam dinding disamping panjangnya adalah $10 \mathrm{~cm}$. Hitunglah panjang lintasan yang dilalui ujung jarum panjang tersebut dengan $\pi=3,14$ jika bergerak selama 45 menit. Konsep apa yang digunakan untuk dapat menyelesaikan soal di atas?

Dari soal tersebut, siswa diminta untuk menghitung keliling lingkaran yang terbentuk dari jarum panjang jam yang berputar selama 45 menit. Hasil tes soal tersebut diperoleh beberapa siswa masih mengalami kekeliruan. Dari 35 siswa dalam menjawab, terdapat 30 siswa menjawab benar dan 5 lainnya masih mengalami kekeliruan dalam menjawab. Adapun kekeliruan 
siswa dalam menjawab umumnya didapati dalam menerjemahkan ide matematis yang diwakili dengan pernyataan “... jika bergerak selama 45 menit". Berikut salah satu contoh jawaban siswa yang keliru.

Keliling lingkaran $=2 \square \times r$

$$
\begin{aligned}
& =2 \times 3,14 \times 10 \\
& =62,8 \mathrm{~cm}
\end{aligned}
$$

Panjang lintasan jika bergerak 45 menit adalah $45 \times 62,8=2826 \mathrm{~cm}$.

Jawaban yang diharapkan dari Soal Nomor 2 adalah siswa menggunakan konsep perbandingan dan keliling lingkaran. Panjang lintasan yang dilalui ujung jarum panjang jam selama 45 menit berarti (45/60) menit atau 3/4 bagian keliling lingkaran.

Untuk mengetahui penyebab kekeliruan siswa dalam menyajikan konsep 3/4 bagian keliling lingkaran, maka dilakukan wawancara dengan fokus pertanyaan pada aspek introspective dan aprioribelieve.

Peneliti : Menurut kamu, ada konsep lain tidak yang harus digunakan untuk menyelesaikan masalah yang ini?

Siswa : Maksudnya gimana bu?

Peneliti : Dalam menyelesaikan masalah yang ini, kamu menggunakan konsep apa?

Siswa : Konsep keliling lingkaran bu.

Peneliti : Baik. Lalu kamu menggabungkannya

dengan konsep apa sehingga diperoleh jawaban sesuai dengan yang kamu tulis?

Siswa : Itukan nyari keliling lingkaran bu, jadi saya gunakan rumus keliling lingkaran. Tapi yang 45 menit saya bingung bu harus diapakan.

Peneliti : Menurut kamu, bagian pembelajaran keliling lingkaran yang mana, yang kamu rasa belum dipahami dengan benar?

Siswa : Ya yang seperti ini bu. Kalau mengerjakan sesuai contoh sih saya bisa bu, tapi kalau udah beda begini, saya suka bingung.

Sebagian skrip wawancara di atas menggambarkan bahwa secara instrospective siswa belum dapat memanfaatkan implementasi materi prasyarat dalam menyelesaikan masalah matematis yang dihadapinya. Dalam hal ini dapat dikatakan bahwa kesan siswa terhadap pengalaman belajar yang telah dilaluinya tidak cukup membekalinya untuk mengaplikasikan konsep matematis yang dipelajari sehingga menyebabkan aprioribelieve yang rendah.

\section{Soal Nomor 3}

Perhatikan gambar pada soal

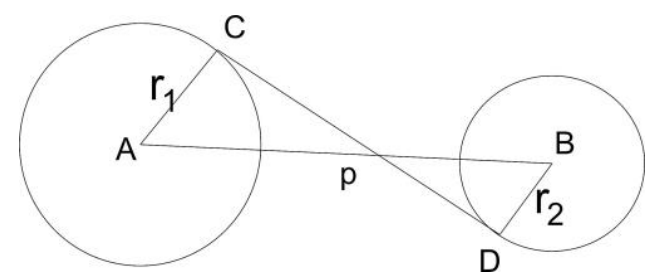

Salinlah gambar pada soal nomor 3, kemudian perpanjanglah garis $A C$. Buatlah garis dari titik $B$ yang sejajar dengan $C D$ sehingga berpotongan dengan perpanjangan $A C$ di titik $O$. Bagaimana panjang $O B$ dan $C D$ ? Hitunglah panjang $O B$ dengan menggunakan teorema Pythagoras.

Pada soal Nomor 3, siswa diminta untuk menemukan panjang $\mathrm{OB}$ 
yang merupakan panjang garis singgung persekutuan dalam CD. Secara tidak langsung, sebenarnya siswa diminta menghitung panjang garis singgung persekutuan dalam lingkaran dengan cara melukis ulang gambar pada soal dan memformulasikan rumus panjang garis singgung persekutuan dalamnya dengan informasi yang terdapat dalam gambar yang siswa buat. Tantangannya, siswa harus mampu menggambar dengan benar agar informasi yang dibutuhkan bisa akurat sehingga dapat digunakan untuk menyelesaikan soal. Namun, dari 35 siswa dalam menjawab Soal Nomor 3, 4 siswa menjawab benar, 17 siswa menjawab salah, dan 14 lainnya tidak menjawab. Adapun contoh jawaban siswa yang keliru ditunjukan pada Gambar 1.

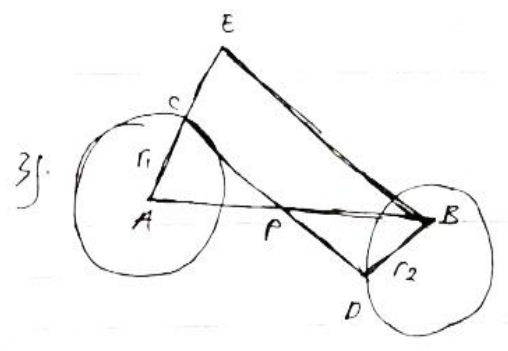

Gambar 1. Contoh jawaban salah soal nomor 3 .

Pada Gambar 1, representasi visual yang siswa buat kurang tepat karena tidak menggunakan alat bantu seperti penggaris dan jangka sehingga informasi yang ada pada soal juga tidak terlihat. Meskipun siswa tidak dapat menyusun formulasi dari panjang segmen garis OB (panjang garis singgung persekutuan dalam atau CD), namun siswa tersebut masih dapat menerjemahkan kesejajaran dua garis yang terjadi pada segmen garis OB dan CD. Untuk menelisik bagaimana cara pandang siswa terhadap konsep garis singgung lingkaran, diajukan beberapa pertanyaan dalam tahap wawancara yang difokuskan pada aspek perseptual dan aprioribelieve.

Peneliti : Coba kamu jelaskan informasi dan permintaan yang ada pada soal?

Siswa : Soal itu minta untuk menggambar ulang bu, tapi saya tidak paham di mana harus meletakkan titik-titik yang diketahui pada soal.

Peneliti : Menurutmu $r_{1}$ dan $r_{2}$ pada soal tersebut artinya apa?

Siswa : Jari-jari bukan sih bu? (sambil menggaruk-garuk kepala tidak yakin)

Peneliti : Betul, itu jari-jari. Coba kamu jelaskan dengan kata-katamu sendiri apa itu jari-jari?

Siswa : Saya tahu kalau d berarti diameter, $r$ berarti jarijari bu.

Peneliti : Oh iya, kamu sudah bagus menerjemahkan

kesejajaran $O B$ dan $C D$. Bagaimana kamu bisa mengingat itu dengan baik?

Siswa : Iya bu, saya ingat betul kalau contoh dua garis sejajar itu seperti rel kereta api, tidak pernah berpotongan.

Peneliti : Baik. Kamu tahu tidak, dalam soal itukan diminta untuk mencari panjang dari segmen garis $O B$. Nah, karena tadi kamu dapat mengatakan bahwa $O B$ sejajar $C D$, sebetulnya soal tersebut meminta kamu menentukan apa sih? 
DOI: https://doi.org/10.24127/ajpm.v9i2.2735

Siswa : Saya nggak ngerti bu, maksud soalnya. Saya belum paham banget tentang materi ini.

Pada skrip wawancara tersebut, terlihat bahwa siswa memiliki aprioribelieve yang cukup baik terhadap materi prasyarat (kesejajaran dua garis) namun memiliki aprioribelieve yang rendah pada materi garis singgung lingkaran. Secara perseptual, siswa dapat menggunakan sebagian pengetahuan yang telah diperolehnya pada konteks yang berbeda, tetapi oleh karena pemahamannya terhadap materi yang sedang dipelajarinya masih rendah maka menyebabkan rendahnya performa dalam menyelesaikan masalah.

\section{Soal Nomor 4}

Rantai sepeda menghubungkan gir depan dan belakang. masing-masing gir tersebut berjari-jari $18 \mathrm{~cm}$ dan 12 $\mathrm{cm}$. Jika jarak titik pusat kedua gir itu adalah $30 \mathrm{~cm}$. berapakah panjang rantai minimal yang menghubungkan kedua gir tersebut agar dapat bergerak?

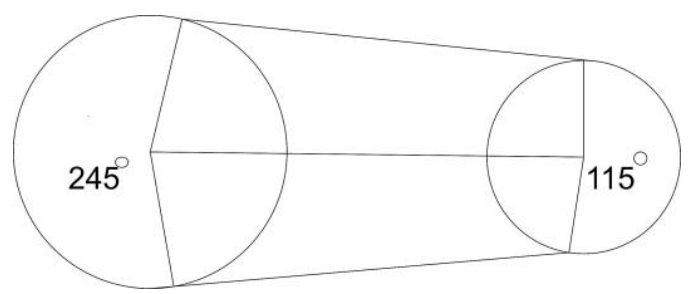

Pada soal Nomor 4, siswa diminta untuk menghitung panjang rantai yang melilit pada kedua gir besar dan kecil yang merupakan aplikasi dari konsep keliling lingkaran dan garis singgung persekutuan luar lingkaran. Pada soal tersebut, siswa harus mengitung panjang rantai yang menempel pada gir besar dan kecil dengan menggunakan konsep keliling lingkaran. Dari 35 siswa yang diberikan soal tersebut, hanya terdapat 2 siswa yang memberikan jawaban, lainnya tidak menjawab. Adapun kekeliruan dari siswa yang menjawab ditunjukan pada Gambar 2.

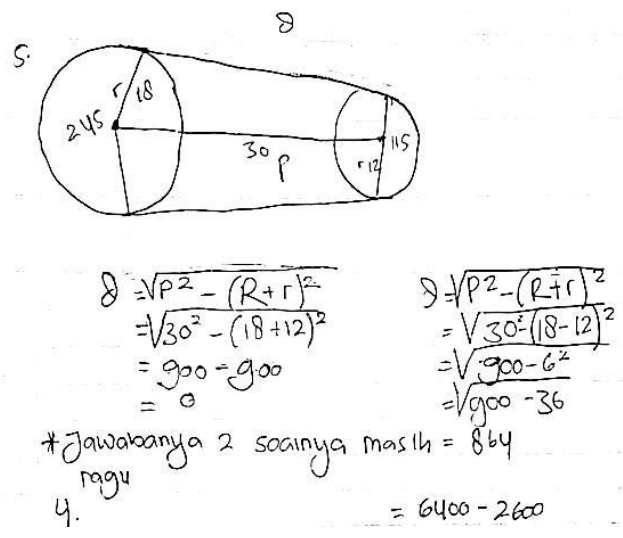

Gambar 2. Contoh jawaban siswa.

$$
\text { 5. } \begin{aligned}
\text { Dik }= & k=18 \\
r & =12 \\
p & =30 \\
\text { Dit } & =d ? \\
d & =\sqrt{p^{2}-(R-r)^{2}} \\
& =\sqrt{30^{2}-(18-12)^{2}} \\
& =\sqrt{30^{2}-6^{2}} \\
& =\sqrt{900-36} \\
& =\sqrt{864}
\end{aligned}
$$

Gambar 3. Contoh jawaban siswa.

Pada Gambar 2 menunjukkan siswa memiliki dua jawaban. Jawaban pertama siswa menghitung panjang garis perekutuan dalam sedangkan jawaban kedua siswa menghitung panjang garis singgung persekutuan luar. Selain itu, siswa tidak mampu menyelesaikan tantangan pada soal untuk menghitung panjang rantai yang melilit, artinya siswa juga harus 
DOI: https://doi.org/10.24127/ajpm.v9i2.2735

menghitung bagian rantai yang menempel pada lingkaran.

Pada Gambar 3, sebenarnya tidak ada yang salah dari jawaban siswa, karena siswa menjawab dengan tepat mengenai panjang salah satu garis singgung persekutuan luarnya. Tetapi dalam hal ini jawaban siswa masih kurang sempurna karena siswa hanya menghitung salah satu panjang garis singgung persekutuan luar dan tidak menghitung rantai yang menempel pada bagian roda atau lingkarannya.

Untuk mengetahui bagaimana persepsi siswa tentang konsep garis singgung lingkaran, dilakukan tahapan wawancara terhadap salah satu subyek yang sama sekali tidak memberikan jawaban.

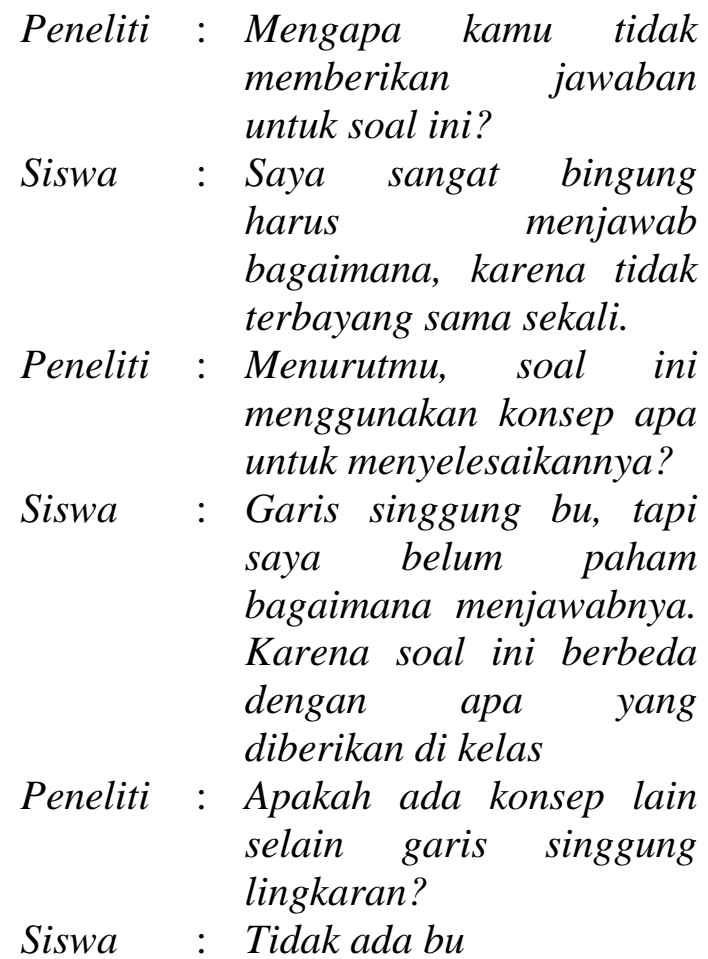

Berdasarkan skrip wawancara untuk soal nomor 4, disimpulkan bahwa secara perseptual siswa belum dapat menyelesaikan soal apabila berbeda dengan apa yang sudah dipelajarinya di kelas atau soal non rutin sehingga secara memorial juga tersirat bahwa kemandirian siswa dalam belajar masih cukup rendah. Apabila ditinjau dari aspek introspective, siswa juga belum dapat mengaitkan satu konsep dengan konsep yang lain dalam menyelesaikan masalah sehingga memiliki aprioribelieve yang kurang baik dalam memahami materi selanjutnya.

Pada deskripsi kemampuan siswa dalam menyelesaikan soal nomor 1 , diperoleh fakta bahwa learning obstacle yang dialami siswa adalah terkait dengan kemampuan siswa dalam merepresentasikan ide matematis ke dalam bentuk representasi simbolik. Adapun penyebab adanya learning obstacle ini berdasarkan hasil wawancara adalah secara perseptual, siswa tidak terbiasa dengan konteks yang tidak rutin. Siswa tidak mendapatkan pengalaman yang cukup di kelas dalam menyelesaikan permasalahan matematis sebagai bentuk aplikasi konsep matematis yang sedang dipelajari. Padahal, pengalaman siswa tersebut akan mempengaruhi kebiasaanya untuk melakukan proses berpikir siswa yang tidak rutin. Selain itu, menerjemahkan ataupun menyajikan ide matematis ke dalam bentuk representasi simbolik merupakan salah satu kemampuan yang berpengaruh pada kinerja penyelesaian masalah (Neria \& Amit, 2004).

Pada deskripsi kemampuan siswa menyelesaikan soal nomor 2, didasarkan pada data hasil tes, learning obstacle siswa terkait dengan merepresentasikan ide matematis ke dalam bentuk representasi visual dan simbolik. Setelah dilakukan penelusuran melalui wawancara, diperoleh temuan bahwa penyebab siswa mengalami learning obstacle jenis tersebut serupa dengan data yang diperoleh pada wawancara untuk soal nomor 1 yakni 
terbatasnya pengalaman siswa dalam mendapatkan konteks-konteks yang tidak baku selama di kelas. Selain itu secara memorial, inisiatif siswa untuk memanfaatkan berbagai sumber belajar juga turut mempengaruhi terjadinya learning obstacle yang dimaksud. Inisiatif siswa dalam hal ini kemandirian belajar turut mempengaruhi keberhasilan seseorang dalam proses pemerolehan pengetahuan. Kemandirian belajar akan berdampak pada tingginya keingintahuan serta keterlibatan siswa dalam proses belajar. Sementara itu, kemandirian belajar yang rendah akan berdampak pada rendahnya keterlibatan siswa dalam proses belajar (Minarni, Napitulu \& Husein, 2016).

Berdasarkan deskripsi siswa dalam menyelesaikan soal nomor 3, jenis learning obstacle yang dialami siswa terkait dengan kemampuan siswa dalam menyajikan ide matematis ke dalam bentuk representasi visual. Kemampuan memvisualisasikan memiliki peran penting dalam mengembangkan proses berpikir dan pemahaman matematis (Lavy, 2006; Surya, Sabandar, Kusumah \& Darhim, 2013).

Data hasil wawancara memberikan gambaran bahwa siswa juga tidak dapat menyelesaikan permasalahan matematis terkait aplikasi konsep matematis dalam kehidupan sehari-hari. Namun demikian, secara introspective siswa memiliki pengalaman belajar yang cukup baik pada materi prasyarat, di mana siswa tersebut menggambarkan penggunaan konsep kesejajaran dalam konteks kehidupan nyata. Secara umum, siswa belum memahami konsep panjang garis singgung lingkaran.

Menurut deskripsi kemampuan siswa dalam menyelesaikan soal nomor 4 , data learning obstacle diambil dari subyek yang tidak memberikan jawaban. Data ini diperoleh melalui proses wawancara. Berdasarkan data hasil wawancara ditemukan bahwa siswa belum paham konsep garis singgung lingkaran dan aplikasi konsep tersebut dalam kehidupan nyata. Ditinjau dari aspek introspective, siswa juga tidak mampu melihat keterkaitan antar konsep matematis, sehingga memiliki aprioribelieve yang rendah terhadap konsep yang berkaitan dengan konsep garis singgung lingkaran.

Data yang diperoleh pada studi ini menggambarkan bahwa secara umum rendahnya kemandirian belajar siswa menyebabkan inisiatif serta keterlibatan siswa dalam belajar juga rendah sehingga menyebabkan pemerolehan pengetahuan baru oleh siswa belum maksimal. Hal ini sesuai dengan hasil studi Minarni, et al. (2016) yang memperoleh gambaran tentang kemampuan pemahaman dan representasi matematis siswa SMP rendah karena disebabkan oleh rendahnya kemandirian belajar serta keterlibatan siswa dalam belajar.

Kemandirian belajar serta keterlibatan siswa selama pembelajaran akan sangat mempengaruhi proses pemerolehan pengetahuan siswa baik ditinjau secara perseptual, memorial, introspective, maupun aprioribelieve. Namun demikian, guru serta sumber belajar lainnya juga turut mempengaruhi kualitas pengetahuan yang diperoleh siswa (Rosita, 2016; Bakar, et al., 2018; Noto, et al., 2018). Sementara itu, salah satu studi Cai \& Ding (2015) menghasilkan bahwa dalam upaya mencapai pemahaman matematis para guru di China menekankan strategi-strategi belajar seperti menemukan kembali suatu konsep, menggunakan dan membandingkan contoh-non contoh 
sehingga terjadi proses penalaran analogi. Dengan demikian, dalam membangun konsep matematis yang secara perseptual dapat memberikan pengalaman belajar yang kaya kepada siswa dapat dilakukan melalui proses penemuan kembali baik di dalam metodenya maupun desain sumber belajarnya. Contoh-contoh permasalahan yang beragam selama pembelajaran juga akan mempengaruhi berkembangnya proses berpikir siswa sehingga akan baik pula pemahaman siswa dalam memeroses informasi yang diterima sebagai suatu pengetahuan yang dapat dibuktikan kebenarannya. Dalam hal ini maka kemampuan siswa dalam memberikan justifikasi untuk setiap permasalahan yang dihadapinya akan semakin berkembang, baik ditinjau secara memorial, introspective, maupun aprioribelieve.

\section{KESIMPULAN DAN SARAN}

Learning obstacle akan menghambat siswa dalam melakukan proses berpikir dan bagaimana memahami suatu konsep. Learning obstacle yang dialami siswa dapat terjadi akibat adanya masalah dalam kesiapan belajarnya, kepemilikan konsep matematisnya, maupun keterurutan materi pelajarannya.

Berdasarkan uraian dalam diskusi dan pembahasan dapat disimpulkan bahwa learning obstacle siswa dalam memahami konsep keliling dan luas lingkaran serta garis singgung lingkaran adalah terkait dengan merepresentasikan ide matematis ke dalam bentuk representasi simbolik dan visual, mengaitkan antar konsep matematis, serta menerapkan konsep matematis dalam kehidupan nyata.

Secara umum terjadinya
learning obstacle yang bersifat
epistemologis pada penelitian ini

disebabkan adanya ketidakmampuan siswa dalam melakukan proses representasi baik secara internal maupun eksternal dalam bentuk representasi simbol dan visual. Hal ini dimungkinkan karena topik matematis yang dibahas adalah terkait geometri khususnya lingkaran dan garis singgung lingkaran. Namun demikian, ini akan membuka peluang studi lanjutan apabila topik matematis yang dibahas didalamnya adalah selain topik-topik geometri.

\section{DAFTAR PUSTAKA}

Aprilia, D., Praja, E.S., \& Noto, M.S. (2018). Desain Bahan Ajar Lingkaran Berbasis Koneksi Matematis Siswa SMP. Jurnal UNION: Jurnal Pendidikan Matematika 6(1), 43-52.

Astuti, R. (2017). Analysis Learning Obstacles Mahasiswa dalam Mempelajari Materi Kombinatorial. Jurnal Edumath 3(1), 56-64.

Bakar, M.T., Suryadi, D. \& Darhim, D. (2019). Learning Obstacles on Linear Equations Concept in Junior Hhigh School Students: Analysis of Intellectual Need of DNR-Based Instructions. Journal of Physics: Conference Series 1157032104.

Brousseau, G. (2002). Theory of Didactical Situations in Mathematics. (N. Balacheff, M. Cooper, R. Sutherland, \& V. Warfield, Eds.) (1st ed., Vol. 19). Dordrecht: Kluwer Academic Publishers.

https://doi.org/10.1007/0-30647211-2

Cai, D. \& Ding, M. (2017). On Mathematical Understanding: Perspectives of Experienced Chinese Mathematics Teachers. Journal of Mathematics Teacher 
Education 20, 5-29.

Cesaria, A. \& Herman, T. (2019). Learning Obstacle in Geometry. Journal of Engineering Science and Technology 14(3), 1271-1280.

Diana, L., Vitaloka, T. Z., Wulandari, F \& Munfi, M. (2019). Learning Obstacle Siswa terhadap Konsep Geometri SMP. Prosiding Seminar Nasional Pendidikan Matematika (pp. 390-399). Cirebon: FKIP Unswagati Press.

Jannah, U.R., Nusantara, T., Sudirman., Sisworo., Yulianto, F.E., \& Amiruddin, M. (2019). Student's Learning Obstacles on Mathematical Understanding of a Function: A Case Study in Indonesia Hugher Education. TEM Journal 8(4), 1409-1417.

Harel, G. \& Sowder, L. (2005) Advanced Mathematical-Thinking at Any Age : Its Nature and Its Development. Mathematical Thingking and Learning (7), 27-50.

Lavy, I. (2006). Dynamic Visualization and The Case of 'Stars in Cages'. Proceedings 30th Conference of The International Group for the Psychology of Mathematics Education (pp. 25-32). Prague : PME.

Minarni, A., Napitulu, E. E., Husein, R. (2016). Mathematical Understanding and Representation Ability of Public Junior High School in North Sumatra. Journal on Mathematics Education 7(1), 45-58.

Neria \& Amit. (2004). Student Preference of Non-Algebraic Representations in Mathematical Comunication. Proceedings of the 28th Conference of The International Group for the Psichology of Mathematics Education (pp.409-416).
Noto, M.S., Pramuditya, S. \& Fiqri, Y. M. (2018). Design of Learning Materials on Limit Function Based Mathematical Understanding. Infinity Journal of Mathematics Education 7(1), 61-68.

Noto, M.S., Priatna, N., \& Dahlan, J. A. (2019). Mathematical Proof: The Learning Obstacles of Pre-Service Mathematics Teachers on Transformation Geometry. Journal on Mathematics Education 10(1), 117-126.

Perbowo, K.S. \& Anjarwati., R. (2017). Analysis of Students' Learning Obstacle on Learning Invers Function Material. Infinity Journal of Mathematics Education 6(2), 169-176.

Prasetyo, N. A., Herman, T., Al Jupri. (2020). Desain Didaktis Berpikir Kreatif Matematis pada Materi Bangun Ruang Sisi Datar Berbantuan Geogebra. Journal on Mathematics Education Research 1(1), 42-48.

Rohimah, S.M. (2017). Analisis Learning Obstacles pada Materi Sistem Persamaan dan Pertidaksamaan Linear Satu Variabel. JPPM Jurnal Penelitian dan Pembelajaran Matematika 10(1), 132-141.

Rosita, C.D. (2014). Kemampuan Penalaran dan Komunikasi Matematis: Apa, Mengapa, dan Bagaimana Ditingkatkan pada Mahasiswa. Jurnal Euclid 1(1), 3359.

Rosita, C.D. (2016). The Development of Courseware Based on Mathematical Representations and Arguments in Number Theory Courses. Infinity Journal of Mathematics Education 5(2), 131140. 
DOI: https://doi.org/10.24127/ajpm.v9i2.2735

Rosita, C. D., Nopriana, T., \& Silvia, I. (2019). Design of Learning Materials on Circle Based on Mathematical Communication. Infinity Journal of Mathematics Education 8(1), 87-98.

Sulistiawati., Suryadi, D., \& Fatimah, S. (2015). Desain Didaktis Penalaran Matematis untuk Mengatasi Kesulitan Belajar Siswa SMP pada Luas dan Volume Limas. Jurnal Matematika Kreatif-Inovatif 6(2), 135-146.

Surya, E., Sabandar, J., Kusumah, Y.S., \& Darhim. (2013). Improving of Junior High School Visual Thinking Representation Ability in Mathematical Problem Solving by CTL. Indonesian Mathematical Society Journal on Mathematics Education 4(1), 113-126.

Suryadi, D. (2013). Didactical Design Research (DDR) dalam Pengembangan Pembelajaran Matematika. Prosiding Seminar Nasional Matematika dan Pendidikan Matematika (pp.3-12). Bandung: STKIP Siliwangi.

Suryadi, D. (2019). Didactical Design Research (DDR) dan Penyusunan Situasi Didaktis Matematika SMP. Makalah Disajikan dalam workshop DDR pada tanggal 9-10 April 2019. Cirebon: FKIP Unswagati Press.

Tall, D. (2002). The Psychology of Advanced Mathematical Thinking. In Advanced Mathematical Thinking (pp. 3-21). Dordrecht: Springer Netherlands. 